\title{
Ownership Structure and Accounting Conservatism: A Literature Review
}

\author{
Fangfang Song \\ Management School, Jinan University, Guangzhou, China \\ Email: 576446778@qq.com
}

Received 18 March 2015; accepted 12 April 2015; published 20 April 2015

Copyright (C) 2015 by author and Scientific Research Publishing Inc.

This work is licensed under the Creative Commons Attribution International License (CC BY). http://creativecommons.org/licenses/by/4.0/

c) (7) Open Access

\begin{abstract}
With the rapid development of modern corporate theory, the divergence of interests of shareholders and management began to increase, leading to more and more conflicts between the shareholders and managers. The agency problem hindered the company and shareholders to maximize their value. A reasonable ownership structure and sound accounting information can alleviate the problems caused by the agency conflict. Therefore, many scholars began to research the relationship between ownership structure and accounting conservatism. This article summarizes the relevant literature mainly from the ownership concentration, the degree of equity checks and balances, institutional ownership and state ownership of these four aspects, in order to provide theoretical support for the follow-up study.
\end{abstract}

\section{Keywords}

Ownership Concentration, Equity Restriction Ratio, Institutional Investors, Accounting Conservatism

\section{Introduction}

Accounting conservatism requires to fully considering the inherent uncertainty of the economic environment, so as to maintain a cautious attitude toward the uncertainty. Accounting conservatism is not only a basic principle in accounting recognition, measurement and reporting, but also an important quality feature of accounting information. Although China's accounting standards are constantly changing and improving, but increasingly importance has not been attached to accounting conservatism. People have not realized the significance of accounting information. And with the extensive use of fair value measurement attribute, the demand for soundness of accounting information is gradually increasing. Watts (1993) [1] considered that accounting conservatism was affected by a series of governance factors. Based on this, scholars need to conduct a systematic research about 
accounting conservatism. An empirical model which is called inverse regression method proposed by Basu (1997) [2] has been widely used by other scholars. He provides a precedent on the empirical study of accounting conservatism.

Ownership structure is an equity stake state formed by nature of the shareholders and the corresponding shares, it represents the ownership arrangements and determines the control structure of a corporation, is the property foundation of corporate governance. The ownership structure of listed companies usually has an impact on financial reporting, the same as the accounting conservatism. To understand the relationships between ownership structure and accounting conservatism, this article will summarize the international research that how ownership concentration, equity restriction ratio, institutional investors and the ultimate property rights influence the accounting conservatism.

\section{Ownership Concentration and Accounting Conservatism}

Concentration of ownership exists in most companies. Shleifer and Vishny (1986) [3] research the US firms which have a relative dispersion of equity. They found that even in these companies, there is a certain degree of ownership concentration. La Porta et al. (1999) [4] studied the large companies in 27 countries from economically developed areas. They think almost all of the equity of these companies did not meet the research of Berle and Means (1932) [5]. Because ownership concentration exists in most companies, the agency conflict between controlling shareholders and minority shareholders also predominate. The controlling shareholders tend to cover up their own interests of minority shareholders through the manipulation of earnings information behavior, reduce the robustness of accounting information.

By research 40,000 firms from common law countries and the civil law countries, Ball et al. (2000) [6] found that the listed companies which had concentrative ownership resolved information asymmetry through private exchange of information, rather than the use of accounting information publicly disclosed. Therefore, the demand for soundness of accounting information is reduced. Fan and Wong (2002) [7] researched the relationship between the structure and the quality of accounting earnings in East Asia. They conducted that the controlling of shareholder is stronger, they would more likely release good news and hide bad news, and in order to whitewash the accounting information, accounting information robustness would decrease. Bushman et al. (2004) [8] found that even the company had a relatively dispersed ownership in US; there are still negative relationship between ownership concentration and accounting conservatism. Lafond (2005) [9] studied the case of Australia, France, Germany, Britain and Japan, found that the higher the concentration of ownership, accounting conservatism worse. Despite the different legal systems in these countries, the conclusions are the same. The reason is that in the companies with concentrate ownership, private communication would be smoothly spread. The large shareholders can be used as a method of supervising management, thereby reducing the need for robustness of accounting information.

In our country, due to the dominance of state-owned shares, the accounting conservatism is deserved to be studied. Cao Yu, Li Lin, Sun Zheng (2005) [10] use A-shares in Shanghai and Shenzhen listed companies of 1997-2001 as the sample and extend the model proposed by Basu (1997) [2]. The empirical results show that when the major shareholders have a strong control of the company, the company may whitewash accounting information, decrease accounting conservatism. By improve the model draw by Basu (1997) [2] and Ball (2000) [6], Zongfeng Xiu (2007) [11] studied the listed companies in 2002-2004 ,and found that when a company has high concentration of equity, major shareholders may be cover up for the expropriation of the interests of minority shareholders by earnings manipulation, thus has a negative impact on accounting earnings. Hongxing Dong (2009) [12] considered the supply and demand for the robustness of accounting information, he supposed that the stronger control of major shareholders, the lower the listed company's accounting conservatism level. Studies have shown that a high proportion of large shareholders will reduce the supply and demand for the robustness of accounting information. The largest shareholder and accounting conservatism have a significant negative correlation.

By summarizing the studies, can find a significant negative relationship between ownership concentration and accounting conservatism. When the ownership concentration increases, the controlling shareholder will be motivated to encroach the interests of minority shareholders, and will go to hide their behavior by manipulating earnings; in addition, ownership concentration increases the role of private communication, reduces the need for robustness of accounting information. Therefore, the ownership concentration reduces accounting conservatism. 


\section{Equity Balance Degree and Accounting Conservatism}

In most studies, scholars usually use the sum of second to fifth shares to measure the equity balance degree, thus to measure the role of supervising the first shareholder. Firstly, all the shareholders need robust accounting information. Secondly, a reasonable ownership structure can encourage the efficient supply of robust accounting information. Therefore, a reasonable ownership structure can ensure the robust accounting information. Volpin (2002) [13] used the Italian companies as a research object. The study found that when the company's control falls in the hands of the controlling shareholder, along with the replacement of management, value of the company is also lower. Maury and Pajuste's (2005) [14] research showed that, with the increase of the degree of equity balance, minority shareholders have also increased monitored controlling shareholders, the higher the value of the company. Foreign scholars found that the value of a company is positive with equity balance degree. This also shows that improving the degree of equity balances can improve corporate governance environment, thereby protecting the interests of minority shareholders to some extent, improve the robustness of accounting conservatism. Zongfeng Xiu (2008) [15], who is from china studied China’s Shanghai and Shenzhen A-share companies .It was found that the high degree of equity restriction can inhibit the major shareholder from encroaching the interests of minority shareholders and improve the robustness of accounting information. Zhanglin Wen (2010) [16] used the sample data from 2005 to 2008 in Shanghai and Shenzhen A-share listed companies, the study found that the higher the degree of the company's equity balance, the stronger its accounting information conservatism.

Equity balance is an equilibrium equity ownership structure. Equity balance helps to inhibit the major shareholder of minority shareholders predatory behavior, and improve the robustness of accounting information, reduce agency conflicts. Ceteris paribus, the higher the equity balance, accounting conservatism is better. Especially due to China's special ownership structure, the establishment of the reasonable ownership structure can actually improve the quality of accounting information.

\section{Institutional Investors and Accounting Conservatism}

About the role of institutional investors on governance, scholars have done a lot of research. There are two views by summarizing existing literature on institutional investors. One thinks that the frequent trade and the small amount of shares discourage the institutional investors to participate in the corporate governance, making them short-sighted and focus only on short-term interests. Another opinion challenges the generally accepted view which says that institutional investors are short-sighted. It proved that institutional investors can actively monitor management, standardized information efficiency.

According to Bushee, Ling Lin (2012) [17] classified institutional investors as short-type, quasi-exponential type and focus of institutional investors. Based on this, he researched the relationship between institutional investors and accounting conservatism. The results showed that short-term and exponential type institutional investors have a short payback period, relatively low stake and diverse investment, the relationship between earnings management and institutional investors are positively correlated. Fengyi Lin, Chung-Min Wu, Tzu-Yi Fang, Jheng-Ci Wun (2014) [18] use Benford's law to study the topic. They use the variable C-score to classify accounting conservatism, and classify institutional investors in accordance with the stake. Studies have shown that a lower proportion of institutional investors and institutional shares make a greater incentive for managers to manipulate accounting earnings. Shuqiang Cheng (2006) [19] studied the relationship between earnings management and institutional investors in China listed companies. He found a higher proportion of institutional investors can effectively inhibit the manipulation of earnings. Shanmin Li et al. (2011) [20] found that institutional ownership has a significant positive impact on earnings management of listed companies. In reference to $\mathrm{Bu}-$ shee, the institutional investors will be divided into positive and negative type, further empirical analysis found that the negative institutional investors have a significant positive correlation with earnings management, and the relationship between positive institutional ownership and earnings management are not significant. According to the results of a comprehensive study of the relationship between institutional investors and earnings management, we found that all the studies about the relationship between the two is not the same. The following research need to be analyzed according to various institutional investors' heterogeneity.

The existence of institutional investors will affect earnings management; will inevitably affect the quality of accounting information released. Scholars from the angle of institutional investors, studied the relationship between the heterogeneity of institutional investors and earnings management, but the study about the impact of 
institutional investors on accounting conservatism, only considered the proportion of institutional investors holding and accounting conservatism, did not consider the different characteristics of institutional investors, nor reached the same conclusion. Chi, Liu and Wang (2009) [21] using C-Score proposed by Khan and Watts (2007) [22] to measure the accounting conservatism. Through studying the 1996-2004 Taiwan's stock market, they found that company governance and accounting conservatism can substitute for each other. The shares of institutional investors are higher, the lower demand for soundness of accounting information. Instead, Ramalingegowda and Yu (2011) [23] using the model proposed by Basu (1997) [2] to measure accounting conservatism. By collect the data of listed companies from 1995 to 2006 in US, they found that the higher the proportion of institutional investors' holdings, the higher the soundness of financial reporting, indicating that institutional investors play a supervisory role itself, reducing the company's proxy problem. Chinese scholar Zhanglin Wen (2010) [16] analyzed the data from 2006 to 2008, he found that the higher the proportion of institutional investors holding of a company, its accounting information is more robust.

Most current research stays at the level of studying the relationship between the proportion of institutional investors holding and accounting conservatism. All the studies did not reach the same conclusion. Although institutional investors hold the same stake, there are various other features, such as the holding period and so on, that may influence the final result.

\section{State Holding and Accounting Conservatism}

The majority of listing corporations in China are controlled by the state; the manager has greater motivation to manipulate earnings. Many scholars research the relationship between state holding and accounting conservatism based on the character of our country's special equity. Wang and Liu (2003) [24] studied the data of 19 listed corporations in China who issued A shares and H shares in 1994-2000. And they found that the higher the proportion of state-owned shares, the worse the information disclosed by the company. Liu and Wang (2006) [25] used the modified model of Basu (1997) [2] to study the listed company in Shanghai and Shenzhen in 19992002, and found that the higher proportion of state ownership, the lower accounting conservatism. Chen and Huang (2007) [26] selected the listed A-share companies in Shanghai and Shenzhen in 2001-2003 as a sample, and used the model of Basu (1997) [2] to the correlation ,they found that the proportion of state shares and accounting conservatism are negatively correlated in Chinese listing corporations. Zhu and Li (2008) [27] thought the insider control, debt soft constraint and government intervention make the state-owned company unwell to disclose accounting information, these companies have a lower earnings quality. Through the study of A-share listing corporations in 2001-2004, they found that the state-owned shareholders would weaken the corporate governance and reduce the conservatism of accounting information.

The phantom of owners in state holding enterprises cause the state shareholder cannot restrict and supervise the opportunism behavior of the insider effectively. At the same time, local government intervene the implementation of the decision-making. The weakened corporate governance will influence the efficiency of corporate governance and reduce the company's quality of accounting information. Many scholars have proved that, the proportion of state shares and accounting conservatism is negative correlated.

\section{Conclusions}

With the development of the theory of Modern Corporation, the separation of ownership and management rights, the agency problem is becoming more and more serious. How to alleviate the agency problem effectively and improve the robustness of accounting information has become the focus of the majority of scholars. Comprehensive study of domestic and foreign scholars found that, the increase of ownership concentration will enhance the agency conflict between controlling shareholders and minority shareholders, reduce the conservatism of accounting information; Ownership structure which is balanced validly can make the agency problem between controlling shareholder and minority shareholders get the corresponding mitigation, improve the accounting conservatism; The state holding will weaken the effect of corporate governance, weaken the robustness of accounting information; About the influence of institutional investors on the accounting conservatism, has not yet reached the same conclusion. In a word, the ownership structure has a significant influence on accounting conservatism, and the balance of ownership structure can improve the robustness of accounting information.

However, some issues remain to be resolved. Firstly, most scholars do empirical analysis by learning Basu's model. We cannot predict whether using other models can get the same conclusions, so we should make more 
use of other methods for more reliable research (such as the C-score). Secondly, many studies have focused on static analysis, and I think by studying the changes of institutional investors and state-owned shareholding ratio before and after to research the discrepancies in conservatism, and then analyze the effect of ownership structure on accounting conservatism dynamically is a new focus. Finally, there are also problems that need additional attention about the research on institutional investors' governance, and our research must consider the heterogeneity of institutional investors. Different classification methods, such as qualitative and quantitative methods, institutional investors will show different characteristics and have the different influence on accounting conservatism. With the gradual improvement of China's capital market and the continuous development of institutional investors, the research on the institutional investors will continue to deepen. Therefore, according to existing research results, the research of heterogeneity of institutional investors combined with the realistic background of our country will have important theoretical significance and practical value.

\section{References}

[1] Watts, R.L. (1993) A Proposal for Research on Conservatism. Unpublished Working Paper, Presented at the AAA Meetings, University of Rochester, San Francisco.

[2] Basu, S. (1997) The Conservatism Principle and the Asymmetric Timeliness of Earnings. Journal of Accounting and Economics, 24, 3-37. http://dx.doi.org/10.1016/S0165-4101(97)00014-1

[3] Shleifer, A. and Vishny R.W. (1986) Large Shareholders and Corporate Control. Journal of Political Economy, 94, 461-488. http://dx.doi.org/10.1086/261385

[4] La Porta, Lopez-de-Silanes and Shleifer (1999) Corporate Ownership around the World. Journal of Finance, 54, 471517.

[5] Berle, A. and Means, C. (1932) The Modern Corporate and Private Properity. MacMillan, New York.

[6] Ball, R., Kothari, S.P. and Robin, A. (2000) The Effect of International Institutional Factors on Properties of Accounting Earnings. Journal of Accounting and Economics, 29, 1-51. http://dx.doi.org/10.1016/S0165-4101(00)00012-4

[7] Fan, J. and Wong, T. (2002) Corporate Ownership Structure and the Informative of Accounting Earnings in East Asia. Journal of Accounting and Economics, 33, 401-425. http://dx.doi.org/10.1016/S0165-4101(02)00047-2

[8] Bushman, R., Chen, Q., Engel, E. and Smith, A. (2004) Financial Accounting Information, Organizational Complexity and Corporate Governance Systems. Journal of Accounting and Economics, 37, 167-201. http://dx.doi.org/10.1016/j.jacceco.2003.09.005

[9] LaFond, R. (2005) The Influence of Ownership Structure on Earnings Conservatism and the Informativeness of Stock Prices: An International Comparison. Working Paper, Massachusetts Institute of Technology, Cambridge.

[10] Cao, Y., Li, L. and Sun, Z. (2005) An Empirical Research on the Impact of Accounting Earnings Conservatism of Control of the Company. Finance and Accounting, 14, 34-42.

[11] Xiu, Z.F. (2007) Whether Large Shareholders and Management Is the Interests of the Cooperative or Conflict-Based on the Evidence of Our Country Listing Corporation. Journal of Shanxi University of Finance and Economics, 10, 117124.

[12] Dong, H.X. (2009) The Control of Large Shareholders and Accounting Conservatism-Evidence from China A Shares of Listing Corporation. Journal of Shanxi University of Finance and Economics, 1, 117-124.

[13] Volpin, P. (2002) Governance with Poor Investor Protection: Evidence from Top Executive Turnover in Italy. Journal of Financial Economics, 64, 61-90. http://dx.doi.org/10.1016/S0304-405X(02)00071-5

[14] Maury, B. and Pajuste, A. (2005) Multiple Large Shareholders and Firm Value. Journal of Banking \& Finance, 29, 1813-1834. http://dx.doi.org/10.1016/j.jbankfin.2004.07.002

[15] Xiu, Z.F. (2008) Ownership Concentration, Equity Balance and Accounting Conservatism. Securities Market Herald, 3 , 40-48.

[16] Wen, Z.L. (2010) An Empirical Study on the Impact of Institutional Investors Holding on the Accounting Conservatism. Enterprise Economy, 2, 154-157.

[17] Lin, L. (2012) Institutional Ownership Composition and Earnings Management. Review of Pacific Basin Financial Markets and Policies, 15, Article ID: 1250022. http://dx.doi.org/10.1142/S0219091512500221

[18] Lin, F.Y., Wu, C.M., Fang, T.Y. and Wun, J.C. (2014) The Relations among Accounting Conservatism, Institutional Investors and Earnings Manipulation. Economic Modelling, 37, 164-174.

[19] Cheng, S.Q. (2006) An Empirical Study on the Institutional Investors and Accounting Earnings Information of the listing Corporation. The Management of the World, 9, 129-136.

[20] Li, S.M., Wang, Y.Y. and Wang, C.P. (2011) An Empirical Study on the Influence of Institutional Investors on Earn- 
ings Management in the Listing Corporation. Management Review, 7, 17-24.

[21] Chi, W., Liu, C. and Wang, T. (2009) What Affects Accounting Conservatism: A Corporate Governance Perspective. Journal of Contemporary Accounting \& Economics, 5, 47-59.

[22] Khan, M. and Watts, R.L. (2007) Estimation and Validation of a Firm-Year Measure of Conservatism. Working Paper, Sloan School of Management, MIT, Cambridge.

[23] Ramalingegowda, S. and Yu, Y. (2011) Institutional Ownership and Conservatism. Journal of Accounting and Economics, 53, 98-114.

[24] Wang, L.Y. and Liu, J.X. (2003) Implementation Deviation of the Accounting Information Disclosure Rule Inside and Outside Listing Corporation-From A-H Shares of Company Evidence Which Exist Dual Reporting Difference. Economic Research, 11, 71-78.

[25] Liu, F.W. and Yang, W. (2006) An Empirical Study on the Impact of Corporate Governance on Accounting Conservatism. Journal of Shanghai Lixin University of Commerce, 3, 16-22.

[26] Chen, X.D. and Huang, D.S. (2007) Corporate Governance and Accounting Conservatism—An Empirical Study Based onlisting Corporation. Securities Market Herald, 3, 10-17.

[27] Zhu, C.F. and Li, Z.W. (2008) Study of State Controlling Effect on Accounting Conservatism. Accounting Research, 5, 38-45. 